\title{
Protective Effect of Caffeic Acid Phenethyl Ester (CAPE) on Ischemia-Reperfusion Injury in Rat Ovary
}

\author{
Efecto Protector de Ester Feniletílico de Ácido Cafeico (CAPE) \\ en la Lesión por Isquemia-Reperfusión en Ovario de Rata
}

Ümit Görkem'; Cihan Togrul ${ }^{1}$; Izzet Sahin²; Bugra Coskun ${ }^{3}$; Mustafa Ozat ${ }^{4}$; Tayfun Güngör ${ }^{1}$ \& Engin Deveci ${ }^{5}$

GÖRKEM, Ü.; TOGRUL, C.; SAHIN, I.; COSKUN, B.; OZAT, M.; GÜNGÖR, T. \& DEVECI, E. Protective effect of caffeic acid phenethyl ester (cape) on 1schemia-reperfusion injury in rat ovary. Int. J. Morphol. 35(1):141-147, 2017.

SUMMARY: The aim of this study was to investigate the effects of caffeic acid phenethyl ester (CAPE) as a prophylactic agent on ischemia/reperfusion (I/R) injury in the rat ovary. A total of 28 Wistar rats were divided into 4 equal groups: (I) sham, (II) ischemia, (III) ischemia + reperfusion, and (IV) IR + CAPE. In groups I and II, ovary torsion was not performed and no drug was administered. In group III, 1 hour of ischemia and 2 hours of reperfusion were performed and no drug was given. Ovarian tissue concentrations of malondialdehyde were significantly higher in the torsion and detorsion groups compared with the sham and Cape groups $(\mathrm{P}<0.005)$. The detorsion group showed preantral ovarian follicles and luteal folicules around the blood vessels and positive expression of CD34. In the CAPE group the stromal vascular endothelium with weak expression of CD34 was detected in small areas, and the ovarian follicles and the corpus luteum showed negative expression of CD34. In the study, Biochemical and histopathological results of CAPE treatment was considered to torsion-detorsioned the model showed a protective effect against tissue damage.

KEY WORDS: Caffeic acid phenethyl ester; Ischemia-reperfusion injury; Ovary; Rat.

\section{INTRODUCTION}

Ovarian torsion often is misdiagnosed (Duigenan et al., 2012). Laparoscopic ovarian-torsion surgery generally is used for ovarian detorsion and to restore blood flow to the ovary. Before surgery, painkillers usually are used for pain control (Fujishita et al., 2015). In neglected or prolonged cases, necrosis develops in ovarian tissue to which blood flow has been cut for a long time. In these cases, surgical removal of the ovaries is required (Kurtoglu et al., 2014). Ovarian detorsion may lead to increased reactive oxygen species (ROS), depending on the recovery of oxygen in the damaged ischemic tissue cells and oxidative tissue damage caused by reperfusion after ischemia (Kumtepe et al., 2010; Sengul et al., 2013). Malondialdehyde (MDA) is the basic product of polyunsaturated fatty acid peroxidation and is quite a toxic molecule. Therefore, it is used to determine in vivo and in vitro oxidative stress levels (Del Rio et al., 2005).

Ovarian ischemia is the result of torsion and leads to cell death because of insufficient perfusion of the tissue
(Halici et al., 2008; Kara et al., 2012). Ischemic tissues need to recover blood supply for regeneration of cells and disposal of toxic metabolites. However, reperfusion of the ischemic tissue paradoxically leads to much more serious damage to the tissue than the damage caused by ischemia (Abramov et al., 2007). Macrophages are major secretory cells capable of releasing cytokines, chemokines and growth factors that function in normal, inflammatory and disease processes of most tissues (Wu et al., 2004). CD34 is a cell surface, sialomucin-like glycoprotein that is expressed on hemopoietic progenitor cells, normal vascular endothelium, and fibroblasts. CD34 is expressed most strongly on primitive hemopoietic cells, and is progressively lost as cells differentiate (Strauss et al., 1986).

CD68 positive cells are localized in human ovaries primarily to the vascular connective tissue and theca-lutein areas of the corpus luteum, although some are found in the granulose-lutein cell layer (Gaytán et al., 1998). The Bcl-2

\footnotetext{
${ }^{1}$ Department of Obstetrics and Gynecology, Hitit University Faculty of Medicine, Çorum.

${ }^{2}$ Department of Obstetrics and Gynecology,Acibadem University, Faculty of Medicine, Istanbul, Turkey.

${ }^{3}$ Department of Obstetrics and Gynecology, Sincan Nafiz Körfez Government Hospital, Ankara, Turkey.

${ }^{4}$ Private Women Health Clinic, Address: Tunus Street No:49/6, Kavaklıdere, Ankara, Turkey.

${ }^{5}$ Department of Histology and Embryology, Dicle University Faculty of Medicine, Diyarbakır, Turkey.
} 
family is known to be a major protein family controlling cell survival or cell death in the molecular pathway of apoptosis. The Bcl-2 family mainly functions as a regulator of mitochondrial membrane permeability and controls the release of apoptogenic factors (Green, 2000; Tsujimoto \& Shimizu, 2000). Caffeic acid phenethyl ester (CAPE) is one of the major components of honeybee propolis and has been used in traditional medicine. It was found to be a potent free radical scavenger and antioxidant (Ilhan et al., 1999). Caffeic acid phenethyl ester (CAPE), an active component of propolis, has been shown to possess anti-inflammatory, immunomodulatory, anticarcinogenic, and antioxidant properties (Song et al., 2002; Irmak et al., 2003; Tsai et al., 2006 \& Altug et al., 2008).

Caffeic acid and its analogues are potential natural antioxidants, and affect free radical scavenging, metallic ion chelation. Additionally, they have inhibitory actions on specific enzymes that induce free radical and lipid hydroperoxide formation. The purpose of this study was to investigate the protective effect of Caffeic acid phenethyl ester on Ischemia-eperfusion injury in an experimental rat adnexal torsion model.

\section{MATERIAL AND METHOD}

The permission for the animal tests and experiments was given by the Animal Ethical Board of Dicle University Medical Faculty.Dicle University's Experimental Animal Laboratory Institute supplied 24 healthy adult female Wistar rats, weighing between 180 and $210 \mathrm{~g}$ The rats were selected according to their estrous cycle. The rats were housed in plastic rat cages at $26 \pm 2^{\circ} \mathrm{C}$ and they were exposed to $10-12$ $\mathrm{h}$ of daylight. Animals were fed a standard laboratory diet and tap water ad libitum. A total of 24 wistar rats were divided into four groups. The rats were first numbered randomly and then randomly divided into 4 equal groups : sham, torsion, detorsion and potentilla fulgens groups In group I $(n=6)$ sham group, in group II ovary torsion was not performed and no drug was administered. In group III h of ischemia and $2 \mathrm{~h}$ of reperfusion were performed and no drug was given.In group IV, CAPE (20 mmol/ $\mathrm{kg})$, which was previously demonstrated to be absorbed transperitoneally (Koltuksuz et al., 1999) was injected i.p. $30 \mathrm{~min}$ before detorsion. Each rat was administered intramuscular ketamine hydrochloride (50 mg/kg ketamine hydroxide) and xylazine hydrochloride (10 mg/kg Rompun, Bayer Istanbul, Turkey) for anesthesia. The rats, except for in the sham-operated group were subjected to right unilateral adnexial torsion which induced ischemia by occlusion of the tuba-ovarian vessels for $2 \mathrm{~h}$. Rats in sham group were subjected to laparatomy only. In the torsion group, ovaries were surgically removed after $2 \mathrm{~h}$ of torsion. Right ovaries were surgically removed in all groups. The ovarian tissues were fixed in 10 $\%$ neutral buffered formalin solution for 24 hours, dehydrated, cleared, and embedded in paraffin as usual. Serial tissue sections at a thickness of 4-5 mm were cut using the microtome and stained with hematoxylin and eosin (H\&E)

Statistical analysis . Data analyses were performed by SPSS 15.0 (SPSS Inc.), and mean and standard deviations were calculated. Whether there were differences between the groups or not was determined by means of Kruskal-Wallis test. Pairwise comparisons were made using MannWhitney U-test. Results were considered statistically significant at $\mathrm{P}$-value $<0.005$.

\section{RESULTS}

The average rank value of the four groups showed statistically significant differences. (Kruskal-Wallis test $=$ $21.1467, p=0.0001$ ), pairwise comparisons of the groups (multiple comparison) statement is as follows.

In control group, ovary was enveloped by a capsule formed of thin fibrous tissue and germinal lining epithelium was cuboidal. In the cortex region, primordial follicles, different-sized seconder, graff follicles and corpus luteum were observed. Granulosa cells around follicles were polygonal, and had eosinophilic-cytoplasm and spherical nucleus with rich chromatin. In the stroma, interstitial cells localized between follicles and vascular structures normal appearances.

In torsion group, hypertrophic follicles and apoptotic cells with degenerative changes were observed. Edema in interstitial region and dilation with hemorrhage in blood vessels were observed.

In torsion-detorsion group, any significant degenerative changes cells were not seen in follicles. A partially decrease in apoptotic cell number, edema in interstitial region and dilation with hemorrhage in blood vessels were observed. Also, an increase in inflammatory cell number was detected.

In torsion-detorsion + CAPE group, follicular cells in the cortex of ovary were observed as polygonal, multilined and a few cells with apoptotic characteristic was seen in cells close to the lumen. In interstitial region, a decrease in inflammatory cell number was observed while no presence of hemorrhage was detected. 
Table I: Ovarian blood plasma concentrations of MDA were significantly higher in the torsion and detorsion groups compared with the sham and cape groups $(\mathrm{P}<0.005)$. Post-hoc analysis.

\begin{tabular}{llll}
\hline \multicolumn{1}{c}{ Groups } & $\mathrm{n}$ & Mean & $\begin{array}{l}\text { Differences of } \\
\text { between groups }\end{array}$ \\
\hline (1) Sham & 6 & 3.1833 & $(2)(3)(4)$ \\
(2) Torsion & 6 & 24.4000 & $(1)(3)(4)$ \\
(3) Torsion-Detorsion & 6 & 19.0833 & $(1)(2)(4)$ \\
(4) Torsion-Detorsion + Cape & 6 & 9.6500 & $(1)(2)(3)$ \\
\hline
\end{tabular}

$\mathrm{p}<0.05$

Table II: Ovarian tissue concentrations of MDA were significantly higher in the torsion and detorsion groups compared with the sham and cape groups $(\mathrm{P}<0.005)$.

\begin{tabular}{lllll}
\hline Groups & $\mathrm{n}$ & Mean & Average Rank & $\begin{array}{l}\text { Different }(\mathrm{P}<0.05) \\
\text { from factor } \mathrm{nr}\end{array}$ \\
\hline (1) 1 Control & 6 & 171,1833 & 15,50 & $(2)(3)(4)$ \\
(2) 2 Torsion & 6 & 135,6667 & 9,50 & $(1)(3)(4)$ \\
(3) 3 Torsion+Detorsion & 6 & 104,9000 & 3,50 & $(1)(2)(4)$ \\
(4) 4 Torsion+Detorsion+Cape & 6 & 301,5667 & 21,50 & $(1)(2)(3)$ \\
\hline
\end{tabular}
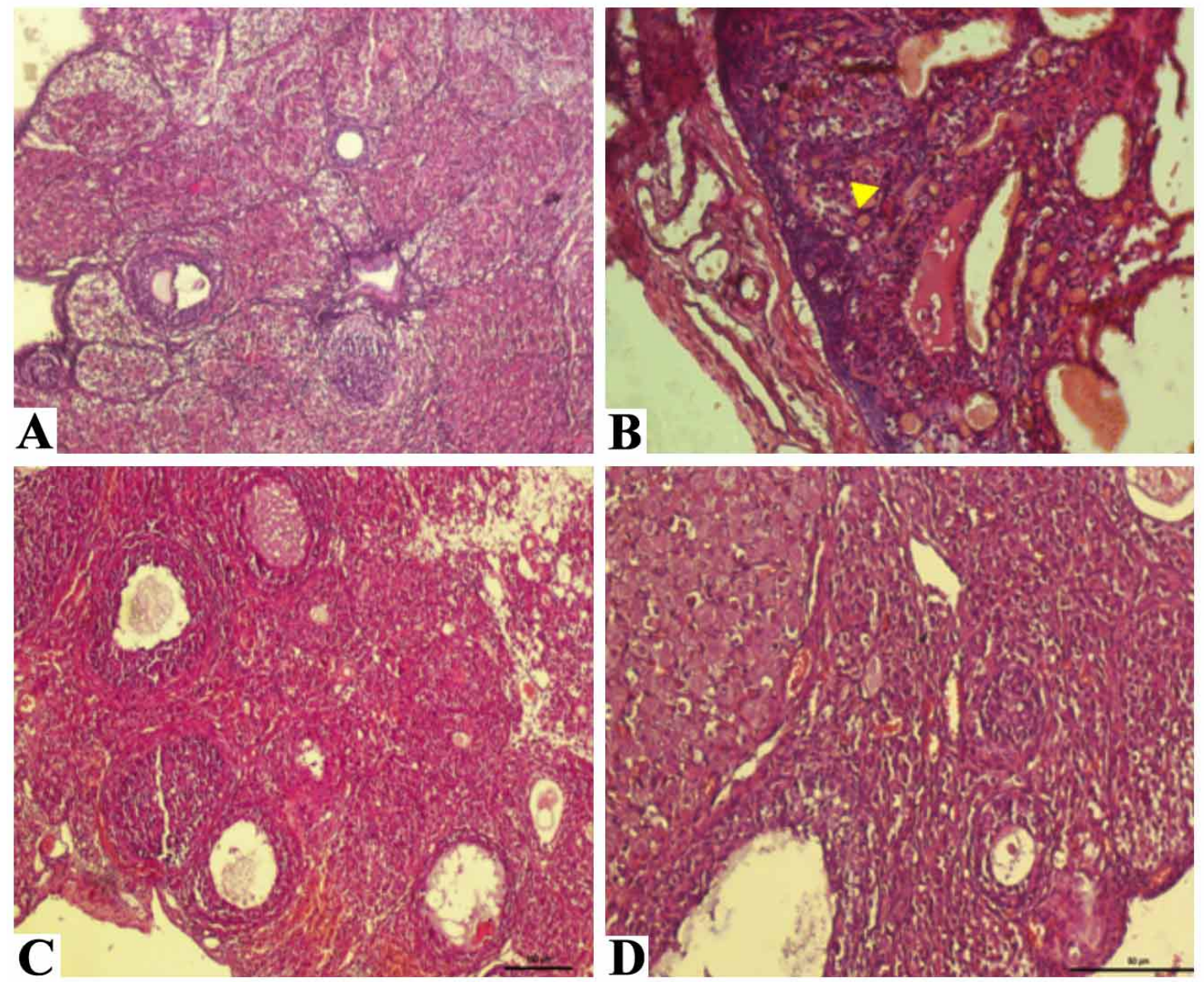

Fig. 1A-Sham group: Normal appereance of ovarian follicules and stromal area H-E staining bar $100 \mu$ m, Figure 1Btorsion group; Dilatation and hemorrhage in blood vessels (star), Hypertrophy and degenerative cells in ovarian follicules arrow), H-E staining bar $100 \mu \mathrm{m}$, Figure 1C- torsion-detorsion group Edema in interstitial region and dilation with hemorrhage in blood vessels (arrow), an increase in inflammatory cell (star) H-E staining bar $100 \mu \mathrm{m}$, Figure 1D- torsion-detorsion + CAPE group A decrease in inflamatory cells and normal appearance of follicular cells. 

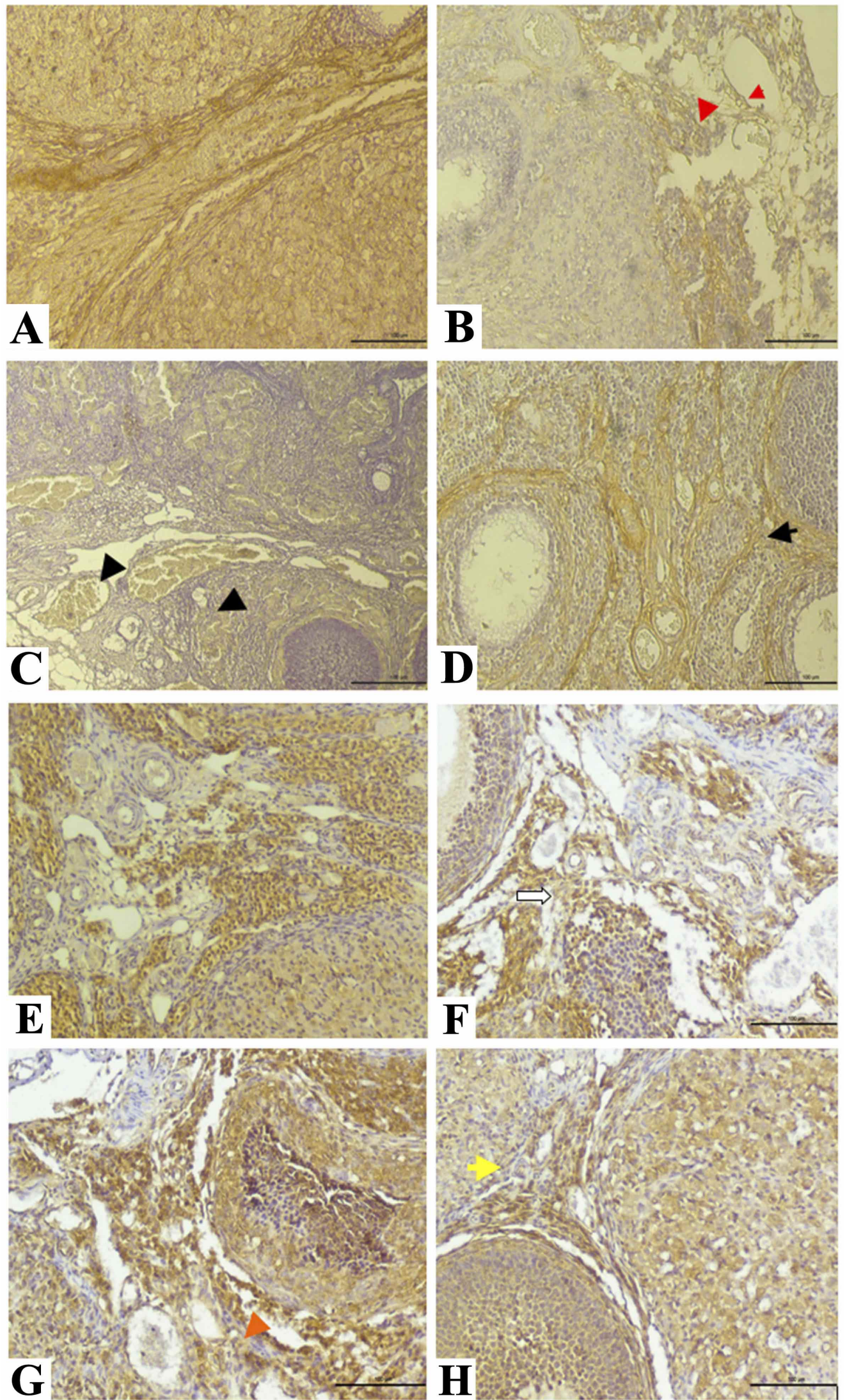

Fig. 2A.Sham group; Immunohistochemical localization of CD34 in ovary.

CD34 immunostaining Bar $100 \mu \mathrm{m}$.

Fig. 2B.Torsion group; Diffuse immunoreactive CD34 positive expression of leukocyte cells and endothelial cells (red arrow) in stromal area, CD34 immunostaining Bar $100 \mu \mathrm{m}$.

Fig. 2C.Torsion-detorsion group; CD34 expression in interfollicular area and positive CD34 expression in endothelial cells (arrow)

Fig. 2D-Torsion-detorsion group + CAPE group,CD34 Positive cells around of regular ovarian folliculares, (arrow) CD34 immunostaining Bar $100 \mu \mathrm{m}$

Fig. 2E. Sham group, Macrophage cells in stromal areas and weak CD68 expression, $\quad$ CD68 immunostaining Bar $100 \mu \mathrm{m}$

Fig. 2F.Torsion group Follicles and interfolicular area with infiltrated macrophages positively immunolabeled with antiCD68 antibody ( a $\mathrm{r} r$ o w ). C D 68 immunostaining Bar $100 \mu \mathrm{m}$.

Fig. 2G.Torsion-detorsion group around blood vessels in stromal areas, positive CD68 expression in granular cells, CD68 immuno staining Bar $100 \mu \mathrm{m}$.

Fig. 2H. Torsion-detorsion group + CAPE group, A decrease in macrophage activity in follicular and stromal area CD68 immunostaining Bar $100 \mu \mathrm{m}$ $\mathrm{AB}$

$\mathrm{CD}$ 

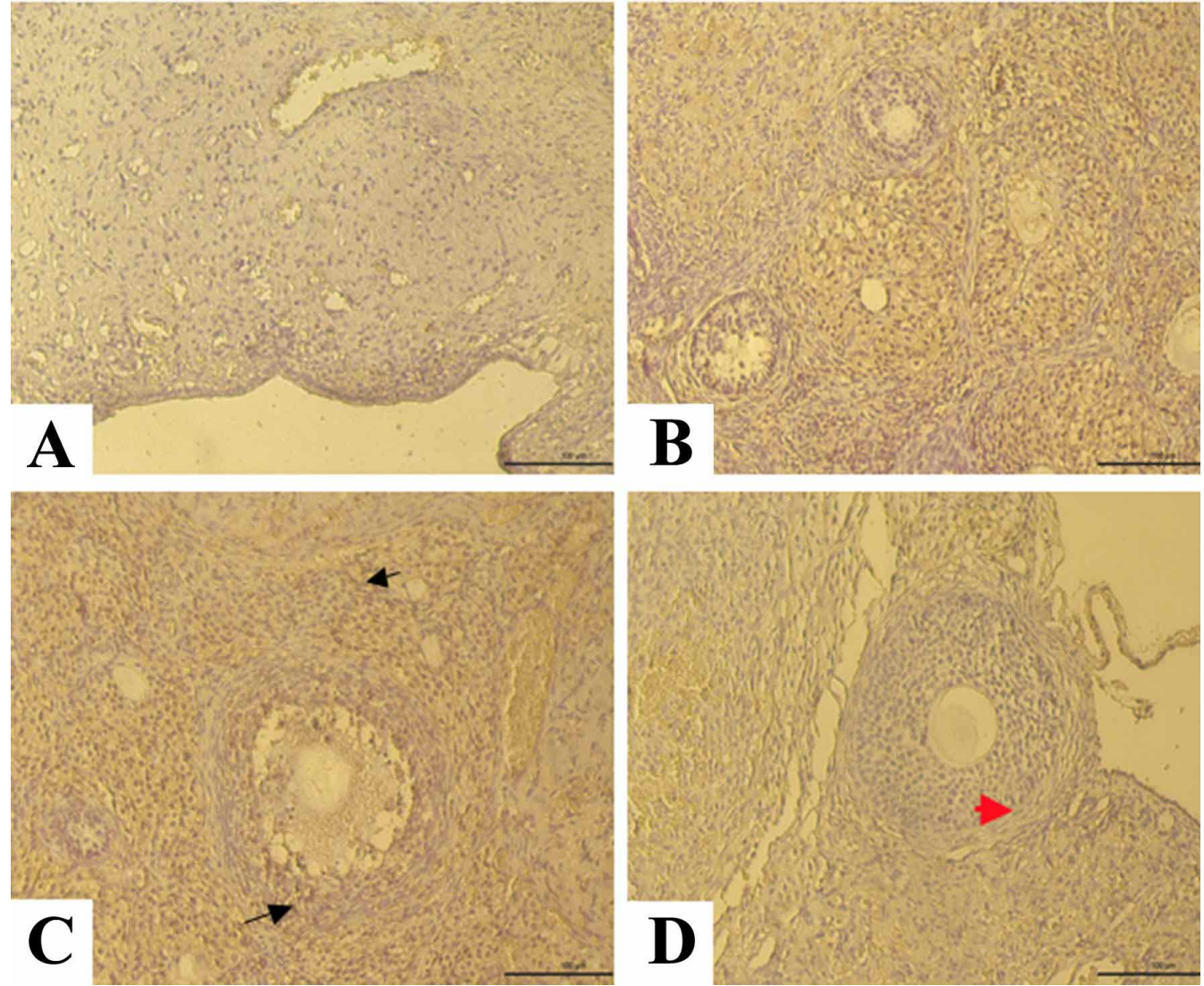

Fig. 3A-Sham group; Negative $\mathrm{Bcl} 2$ reaction ovarian folliculares and stromal area Figure 3B- Torsion group; An increase in Bcl 2 positive cells (arrow) Figure 3C-- Torsion-detorsion group, positive Bcl-2 expression in preantral, luteal folliculi and interfollicular area (arrow) Figure 3D-Torsion-detorsion group + CAPE group, A reduction in the number of apoptotic cells in secondary follicules (red arrow) Bcl-2 immunostaining Bar $100 \mu \mathrm{m}$

\section{DISCUSSION}

There are mechanisms that trigger one another on the basis of ischemia-reperfusion (I/R). Tissue damage mediated by free oxygen radicals are one of those mechanisms. These radicals harm tissue via lipid peroxidation. By this way, they can cause cellular damage. Malondialdehyde (MDA) is used as marker of lipid peroxidation. After ischemia, edema was seen both inside and outside of cells due to endothelium and cell membrane dysfunctionality. Lumen of capillary vessels becomes smaller because of swelling in endothelial cells and liquid leaking outside of vessel, and severe insufficiency will appear in microcirculation even though reperfusion is performed.

CAPE is a molecule that honey bee produces from propolisin. It is a powerful immuno-modulator, anticarcinogenic, anti-inflammatory and anti-oxidant (Elmali et al., 2002).
All in all, it is thought that CAPE can show healing effects in ovary ischemia-reperfusion damage due to its antioxidant and anti-inflammatory properties. Toxic metabolites such as MDA and ROS are increased due to ovarian torsion. This ischemic process is dangerous for cells because of increasing toxic molecules (Yamamoto et al., 1997). The primary pathophysiologic event in ovarian torsion is ischemia followed by reperfusion; thus, ovarian torsiondetorsion is an I/R injury of the ovaries (Barboni et al., 2000 \& Aydogan et al., 2007). Detorsion operations to protect the ovarian reserve result in reperfusion injury, which worsens the tissue damage (Li \& Jackson, 2002). When a tissue suffers from I/R, inflammatory cells cause generation of ROS, which increases leukocyte activation (particularly neutrophiles) and leads to tissue damage and apoptosis (Liou et al., 2003; Parlakpinar et al., 2005). MDA is a stable metabolite of the lipid peroxidation cascade. It is considerably elevated in $I / R$ 
injury, which is believed to cause damages to the integrity and permeability of the cell wall (Akgür et al., 1993; Carden \& Granger, 2000 \& Vural et al., 2004). Ergun et al. (2010), found that plasma and ovarian tissue concentrations of MDA were significantly higher in the torsion and detorsion groups compared with the sham group. CAPE administration protected the heart from I/R injury with reduced levels of oxidative stress such as MDA (Parlakpinar et al.). In our study, CAPE administration reduced MDA to a level comparable to that seen in the control group.

Cellular damage and the damage-associated molecular pattern molecules (DAMPs) induced by high ROS levels can initiate an immune response in the sterile inflammatory response, and then histamine release by activated mast cells, chemokines and proinflammatory cytokines released by stimulated macrophages trigger neutrophil migration into tissue (Jaeschke \& Smith, 1997; Nathan, 2006; Chen \& Nuñez, 2010. \& van Golen et al., 2012).

Many studies have shown that oxidative stress and excessive inflammatory products, depending on their densities in I/R injuries, cause either reversible cell damage or irreversible, lethal, cell damage, such as apoptosis and necrosis (Eefting et al., 2004 \& Linkermann et al., 2013). Bcl-2 overexpression attenuates lipid peroxidation induced by various kinds of agents and protects cells or facilitates their recovery from hydrogen peroxide-induced oxidative DNA damage (Krusche et al., 2002).

Macrophages are able to regulate cellular proliferation, differentiation and apoptosis, as well as influence steroid production, vascularization and tissue remodelling during follicle growth, ovulation and luteinization. It is important to consider that the marker used to identify macrophages reveals specific information about the changing functional characteristics of the cells; for instance, in the rabbit, luteolysis was associated with an initial increase in scavenger receptor positive macrophages followed by recruitment of CD68 positive macrophages (Song et al.).

In our study, in ischemia and ischemia reperfusion group, the expression of CD68 follicles of granular cells, stromal vascular cells in the corpus luteum around and has been shown to positively marked.

CAPE administration protected the heart from I/R injury with reduced levels of oxidative stress such as MDA (Grace, 1994). In our study, CAPA administration reduced MDA to a level comparable to that seen in the control group.

Ischemia injury is associated with alteration of the molecules controlling cell survival and apoptosis in ovary. Bcl-
2 cytoplasmic expression was seen in the granulosa and luteal cells (Jang \& Surh, 2003). Many studies have shown that the effects of some chemical substances on I/R injury in rat ovaries (Bayir et al., 2012 \& Osmanag $\breve{a o g}$ lu et al., 2012). In the study, biochemical and histopathological results of CAPE treatment was considered to torsion-detorsioned the model showed a protective effect against tissue damage.

GÖRKEM, Ü.; TOGRUL, C.; S,AHIN, I.; COSKUN, B.; OZAT, M.; GÜNGÖR, T. \& DEVECI, E. Efecto protector de ester fenetílico de ácido cafeico (CAPE) en la lesión por 1squemia-reperfusión en ovario de rata Int. J. Morphol., 35(1):141-147, 2017.

RESUMEN: El objetivo de este trabajo consistió en investigar los efectos del éster fenetílico del ácido cafeico (EFAC) como agente profiláctico en la lesión por isquemia/reperfusión (I / R) en el ovario de rata. Un total de 28 ratas Wistar se dividieron en 4 grupos iguales: (I) control, (II) isquemia, (III) isquemia + reperfusión, y (IV) IR + EFAC. En los grupos I y II, no se realizó torsión ovárica y no se administró ningún fármaco. En el grupo III, se provocó una hora de isquemia, dos horas de reperfusión y no se administró ningún fármaco. Las concentraciones de malondialdehído en los tejidos ováricos fueron significativamente mayores en los grupos de torsión y de destorsión, en comparación con los grupos sham y de EFAC (P $<0,005)$. El grupo de destorsión mostró folículos ováricos preantrales y folículos lúteos alrededor de los vasos sanguíneos y expresión positiva de CD34. En el grupo EFAC el endotelio vascular estromal con expresión débil de CD34 se detectó en áreas pequeñas, y los folículos ováricos y el cuerpo lúteo mostraron expresión negativa de CD34. En el estudio, fueron considerados los resultados bioquímicos e histopatológicos del tratamiento EFAC en relación a la torsióndestorsión, desarrollando un modelo que mostró un efecto protector contra el daño tisular.

PALABRAS CLAVE: Éster fenetílico de ácido cafeico; Lesion por isquemia-reperfusion; Ovario; Rata.

\section{REFERENCES}

Abramov, A .Y.; Scorziello, A. \& Duchen, M. R. Three distinct mechanisms generate oxygen free radicals in neurons and contribute to cell death during anoxia and reoxygenation. J. Neurosci., 27(5):1129-38, 2007.

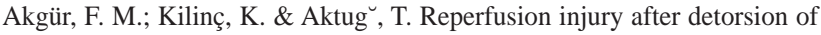
unilateral testicular torsion. Urol. Res., 21(6):395-9, 1993.

Altug, M. E.; Serarslan, Y.; Bal, R.; Kontas s, T.; Ekici, F.; Melek, I. M.; Aslan, H. \& Duman, T. Caffeic acid phenethyl ester protects rabbit brains against permanent focal ischemia by antioxidant action: a biochemical and planimetric study. Brain Res., 1201:135-42, 2008.

Aydogan, H.; Gurlek, A.; Parlakpinar, H.; Askar, I.; Bay-Karabulut, A.; Aydogan, N.; Fariz, A. \& Acet, A. Beneficial effects of caffeic acid phenethyl ester (CAPE) on the ischaemia-reperfusion injury in rat skin flaps. J. Plast. Reconstr. Aesthet. Surg., 60(5):563-8, 2007.

Barboni, B.; Turriani, M.; Galeati, G.; Spinaci, M.; Bacci, M. L.; Forni, M. \& Mattioli, M. Vascular endothelial growth factor production in growing pig antral follicles. Biol. Reprod., 63(3):858-64, 2000.

Bayir, Y.; Karagoz, Y.; Karakus, E.; Albayrak, A.; Sengul, O.; Can, I.; Yayla, N.; Kuskun, U. \& Keles, M. S. Nigella sativa reduces tissue damage in rat 
ovaries subjected to torsion and detorsion: oxidative stress, proinflammatory response and histopathological evaluation. Gynecol. Obstet. Invest., 74(1):419, 2012.

Carden, D. L. \& Granger, D. N. Pathophysiology of ischaemia-reperfusion injury. J. Pathol., 190(3):255-66, 2000.

Chen, G. Y. \& Nuñez, G. Sterile inflammation: sensing and reacting to damage. Nat. Rev. Immunol., 10(12):826-37, 2010.

Del Rio, D.; Stewart, A. J. \& Pellegrini, N. A review of recent studies on malondialdehyde as toxic molecule and biological marker of oxidative stress. Nutr. Metab. Cardiovasc. Dis., 15(4):316-28, 2005.

Duigenan, S.; Oliva, E. \& Lee, S. I. Ovarian torsion: diagnostic features on CT and MRI with pathologic correlation. A. J. R. Am. J. Roentgenol., 198(2):W122- 131, 2012.

Eefting, F.; Rensing, B.; Wigman, J.; Pannekoek, W. J.; Liu, W. M.; Cramer, M. J.; Lips, D. J. \& Doevendans, P. A. Role of apoptosis in reperfusion injury. Cardiovasc. Res., 61(3):414-26, 2004.

Elmali, N.; Ayan, I.; Türköz, Y.; Mizrak, B.; Germen, B. \& Bora, A. Effect of caffeic acid phenethyl ester on cartilage in experimental osteoarthritis. Rheumatol. Int., 22(6):222-6, 2002.

Ergun, Y.; Koc, A.; Dolapcioglu, K.; Akaydin, Y.; Dogruer, G.; Kontas, T.; Kozlu, T. \& Aslan, E. The protective effect of erythropoietin and dimethylsulfoxide on ischemia-reperfusion injury in rat ovary. Eur. J. Obstet. Gynecol. Reprod. Biol., 152(2):186-90, 2010.

Fujishita, A.; Araki, H.; Yoshida, S.; Hamaguchi, D.; Nakayama, D.; Tsuda, N. \& Khan, K. N. Outcome of conservative laparoscopic surgery for adnexal torsion through one-stage or two-stage operation. J. Obstet. Gynaecol. Res., 41(3):411-7, 2015.

Gaytán, F.; Morales, C.; García-Pardo, L.; Reymundo, C.; Bellido, C. \& Sánchez-Criado, J. E. Macrophages, cell proliferation, and cell death in the human menstrual corpus luteum. Biol. Reprod., 59(2):417-25, 1998.

Green, D. R. Apoptotic pathways: paper wraps stone blunts scissors. Cell, 102(1):1-4, 2000

Grace, P. A. Ischaemia-reperfusion injury. Br. J. Surg., 81(5):637-47, 1994. Halici, Z.; Karaca, M.; Keles, O. N.; Borekci, B.; Odabasoglu, F.; Suleyman, H.; Cadirci, E.; Bayir, Y. \& Unal, B. Protective effects of amlodipine on ischemia-reperfusion injury of rat ovary: biochemical and histopathologic evaluation. Fertil. Steril., 90(6):2408-15, 2008.

Ilhan, A.; Koltuksuz, U.; Ozen, S.; Uz, E.; Ciralik, H. \& Akyol, O. The effects of caffeic acid phenethyl ester (CAPE) on spinal cord ischemia/reperfusion injury in rabbits. Eur. J. Cardiothorac. Surg., 16(4):458-63, 1999.

Irmak, M. K.; Fadillioglu, E.; Sogut, S.; Erdogan, H.; Gulec, M.; Ozer, M.; Yagmurca, M. \& Gozukara, M. E. Effects of caffeic acid phenethyl ester and alpha-tocopherol on reperfusion injury in rat brain. Cell Biochem. Funct., 21(3):283-9, 2003.

Jaeschke, H. \& Smith, C. W. Mechanisms of neutrophil-induced parenchymal cell injury. J. Leukoc. Biol., 61(6):647-53, 1997.

Jang, J. H. \& Surh, Y. J. Potentiation of cellular antioxidant capacity by Bcl2: implications for its antiapoptotic function. Biochem. Pharmacol., 66(8):1371-9, 2003

Kara, M.; Daglioglu, Y. K.; Kuyucu, Y.; Tuli, A. \& Tap, O. The effect of edaravone on ischemia-reperfusion injury in rat ovary. Eur. J. Obstet. Gynecol. Reprod. Biol., 162(2):197-202, 2012.

Koltuksuz, U.; Ozen, S.; Uz, E.; Aydinç, M.; Karaman, A.; Gültek, A.; Akyol, O.; Gürsoy, M. H. \& Aydin, E. Caffeic acid phenethyl ester prevents intestinal reperfusion injury in rats. J. Pediatr. Surg., 34(10):1458-62, 1999.

Krusche, C. A.; Vloet, T. D.; Herrler, A.; Black, S. \& Beier, H. M. Functional and structural regression of the rabbit corpus luteum is associated with altered luteal immune cell phenotypes and cytokine expression patterns. Histochem. Cell Biol., 118(6):479-89, 2002.

Kumtepe, Y.; Odabasoglu, F.; Karaca, M.; Polat, B.; Halici, M. B.; Keles, O. N.; Altunkaynak, Z. \& Gocer, F. Protective effects of telmisartan on ischemia/ reperfusion injury of rat ovary: biochemical and histopathologic evaluation. Fertil. Steril., 93(4):1299-307, 2010.

Kurtoglu, E.; Kokcu, A. \& Danaci, M. Asynchronous bilateral ovarian torsion. A case report and mini review. J. Pediatr. Adolesc. Gynecol., 27(3):122-4, 2014.
Li, C. \& Jackson, R. M. Reactive species mechanisms of cellular hypoxiareoxygenation injury. Am. J. Physiol. Cell Physiol., 282(2):C227-41, 2002. Linkermann, A.; Bräsen, J. H.; Darding, M.; Jin, M. K.; Sanz, A. B.; Heller, J. O.; De Zen, F.; Weinlich, R.; Ortiz, A.; Walczak, H.; Weinberg, J. M.; Green, D. R.; Kunzendorf, U. \& Krautwald, S. Two independent pathways of regulated necrosis mediate ischemia-reperfusion injury. Proc. Natl. Acad. Sci. U. S. A., 110(29):12024-9, 2013.

Liou, K. T.; Shen, Y. C.; Chen, C. F.; Tsao, C. M. \& Tsai, S. K. Honokiol protects rat brain from focal cerebral ischemia-reperfusion injury by inhibiting neutrophil infiltration and reactive oxygen species production. Brain Res., 992(2):159-66, 2003.

Michaluart, P.; Masferrer, J. L.; Carothers, A. M.; Subbaramaiah, K.; Zweifel, B. S.; Koboldt, C.; Mestre, J. R.; Grunberger, D.; Sacks, P. G.; Tanabe, T. \& Dannenberg, A. J. Inhibitory effects of caffeic acid phenethyl ester on the activity and expression of cyclooxygenase-2 in human oral epithelial cells and in a rat model of inflammation. Cancer Res., 9(10):2347-52, 1999.

Nathan, C. Neutrophils and immunity: challenges and opportunities. Nat. Rev. Immunol., 6(3):173-82, 2006.

Osmanagaoglu, M. A.; Kesim, M.; Yulug „ّ, E.; Mentes, e, A. \& Karahan, C. S. The effect of high dose methylprednisolone on experimental ovarian torsion/ reperfusion injury in rats. Geburtshilfe Frauenheilkd., 72(1):70-4, 2012.

Parlakpinar, H.; Sahna, E.; Acet, A.; Mizrak, B. \& Polat, A. Protective effect of caffeic acid phenethyl ester (CAPE) on myocardial ischemia-reperfusioninduced apoptotic cell death. Toxicology, 209(1):1-14, 2005.

Sengul, O.; Ferah, I.; Polat, B.; Halici, Z.; Bayir, Y.; Yilmaz, M.; Kilic, N. \& Keles, O. N. Blockade of endothelin receptors with bosentan limits ischaemia/ reperfusion-induced injury in rat ovaries. Eur. J. Obstet. Gynecol. Reprod. Biol., 170(2):458-63, 2013.

Song, Y. S.; Park, E. H.; Hur, G. M.; Ryu, Y. S.; Lee, Y. S.; Lee, J. Y.; Kim, Y. M. \& Jin, C. Caffeic acid phenethyl ester unhibits nitric oxide synthase gene expression and enzyme activity. Cancer Lett., 175(1):53-61, 2002.

Strauss, L. C.; Rowley, S. D.; la Russa, V. F.; Sharkis, S. J.; Stuart, R. K. \& Civin, C. I. Antigenic analysis of hematopoiesis. V. Characterization of My10 antigen expression by normal lymphohematopoietic progenitor cells. Exp. Hematol., 14(9):878-86, 1986.

Tsai, S. K.; Lin, M. J.; Liao, P. H.; Yang, C. Y.; Lin, S. M.; Liu, S. M.; Lin, R. H.; Chih, C. L. \& Huang, S. S. Caffeic acid phenethyl ester ameliorates cerebral infarction in rats subjected to focal cerebral ischemia. Life Sci., 78(23):2758-62, 2006.

Tsujimoto, Y. \& Shimizu, S. Bcl-2 family: life-or-death switch. F. E. B. S. Lett., 466(1):6-10, 2000.

van Golen, R. F.; van Gulik, T. M. \& Heger, M. The sterile immune response during hepatic ischemia/reperfusion. Cytokine Growth Factor Rev., 23(3):6984, 2012.

Vural, H.; Aksoy, N. \& Ozbilge, H. Alterations of oxidative-antioxidative status in human cutaneous leishmaniasis. Cell Biochem. Funct., 22(3):153-6, 2004.

Wu, R.; Van der Hoek, K. H.; Ryan, N. K.; Norman, R. J. \& Robker, R. L. Macrophage contributions to ovarian function. Hum. Reprod. Update, 10(2):119-33, 2004.

Yamamoto, S.; Konishi, I.; Tsuruta, Y.; Nanbu, K.; Mandai, M.; Kuroda, H.; Matsushita, K.; Hamid, A. A.; Yura, Y. \& Mori, T. Expression of vascular endothelial growth factor (VEGF) during folliculogenesis and corpus luteum formation in the human ovary. Gynecol. Endocrinol., 11(6):371-81, 1997.

\section{Corresponding author:}

Dr. Engin Deveci

Department of Histology and Embryology

Dicle University Faculty of Medicine

Diyarbakır

TURKEY

Received: 31-07-2016

Accepted: 14-11-2016

Email: engindeveci64@gmail.com 